\title{
Perception of Farmers on Extension Services in North Western Part of Nigeria: The Case of Farming Households in Kano State
}

\author{
Hassan Ibrahim, Jing Zhou, Min Li, Qichang Chen \\ College of Economics and Management, Shenyang Agricultural University, Liaoning, China \\ Email: hassanibrahim449@yahoo.com, zijm08@163.com, qic chen@163.com
}

Received 20 January 2014; revised 21 February 2014; accepted 18 March 2014

Copyright (C) 2014 by authors and Scientific Research Publishing Inc.

This work is licensed under the Creative Commons Attribution International License (CC BY). http://creativecommons.org/licenses/by/4.0/

c) (i) Open Access

\begin{abstract}
This study was conducted to determine the perception of farmers on extension services of ADP in Kano state of Nigeria. Multistage sampling technique was used, in which three local governments were randomly selected. Secondly, three wards (divisions under local government) from the selected local governments (Danbatta, Gaya and Madobi) were randomly selected. Thirdly, three villages (one from each ward) were selected. The total number of sample respondent was 120, i.e. 40 farming households from each village. The data collected were analyzed with SPSS using descriptive statistics, and Likert scale. The results revealed that, farmers of 35 years of age and below have the highest percentage and 105 out of 120 farmers interviewed were found to be literate. The farmers ranked radio as first extension methods, followed by farm and home visit. Finally, to satisfy their need, farmers should be involved in planning and implementation of extension service.
\end{abstract}

\section{Keywords}

Extension Service, Farmers, Extension Methods, Nigeria

\section{Introduction}

Agriculture is the key to Nigerian economy accounting for about $40 \%$ of GDP and employing about $70 \%$ of the active population of over 140 million people [1]. More than half of the populations live in the rural area. It is without contest the leading agricultural power and the largest market in West Africa [2].

82 million hectares out of Nigeria’s total land of 91 million hectares were found to be arable. However, only $42 \%$ of the cultivable area was farmed and the majority of farmers have an average farm size of 1.2 ha [3]. Agricul- 
ture remains a key components of Nigeria’s economy, but, the sector significantly underperformed its potentials [4].

Agricultural extension as a system aims to exchange information and transfer skills between farmers, extension workers and researchers to help identify farming problems. This is achievable through an informal, adult training, communicating with individual members of farmers community advice, an assistance with respect to knowledge and methods of technical agriculture, with due consideration of the economic and social circumstances of the individual and other people collectively [5]. A nut shell extension is an educational process that uses varieties of methods designed to help farmers improve living standard. Similarly, extension methods could be used for understanding the best ways to handle farmers so as to meet their need.

Extension organization seeks for employees who are competent in at least five different areas. Namely, technical competency or level of knowledge and understanding related to the crops and livestock that farmer produces; economic competence, or the ability to weigh alternative productive input and output to determine whether the adoption of new idea is advantageous; science competency or an understanding of the philosophy of science and ability to conduct simple field experiment to test an innovation and assess result [6]. Traditionally, extension was concentrating on training farmers, increasing production and transferring technology. Today's understanding of extension goes beyond technology transfer to facilitation, beyond training to learning and helping farmers to help themselves, in other words assisting farmers on how to think not on what to think.

Nigeria has the largest national agricultural research and extension NRES), made up of 17 commodity-based research institute, specialized national agricultural extension institute, 18 faculties of agriculture in regular federal universities, 3 specialized university of agriculture, and one international agricultural research Centre (IITA) [7].

In Nigeria, agricultural development program (ADP) plays the role of extension delivery services in the agricultural sector. It refers to the research institute for improved technology, in order to effectively deliver services to the farmers. The problems that emanate from agriculture at grass root levels are transfer to the scientist by the extension personnel and the solution in form of improved technology are disseminated to the farmers for implementation [8]. The major challenges of Nigeria's agricultural extension services have been identified to include: lack of legislated agricultural extension policy, inadequate and untimely funding, poor leadership and coordination, low private participation, very weak research-extension-farmer inputs linkage system driven by ineffective top-down, supply-driven extension approaches [9].

Ayesha and Mohammad [10], reported that in many developing countries, wide adoption of research results by majority of farmers remain quite limited. This situation calls for smooth flow of information from farmers to researchers and from researcher to farmers this passage is provided by agricultural extension services. But, unfortunately extension services have failed in performing its role efficiently and effectively. This research work is to find out the effectiveness of different extension methods used by extension personnel in disseminating improved agricultural technologies to farmers.

\subsection{Problem Statement}

According to Anandajayasekeram [11], in a rapidly changing world, food and agricultural innovation system are facing new and increasing complex challenges: Fighting poverty, ensuring food security and improving living standard of farmers. New mechanism to foster development and diffusion of innovation are needed to strengthen the ways in which information, knowledge and technology are developed and disseminated to ensure that the global changes benefit small holder farmer. Similarly, agricultural extension service operates from the backdrop belief that increased agricultural productivity depends primarily upon the acceptance of improved cultural and technological changes at the rural farm level and that peasant farmers can achieve higher farm yields only if they adopt recommended scientific farming techniques in place of their traditional practices. These could only be channeled through effective extension services which are assessed from the farmers' view point. However, extension services in Nigeria perform poorly.

\section{Significance}

This research will bring out farmers view point on the effectiveness of extension service provided by Kano State government of Nigeria through Agricultural Development Program (ADP). Hence, preconditions for extension agents to be effective include ability to communicate, attitude to extension work, frequency of contact with far- 
mers and field responsibility, which are all examined on farmers`view point. More so, extension effectiveness will be determined by the level of awareness of extension service created among farmers. This research will assist in providing more information about farmers and government effort toward agricultural development, hence aid in policy formulation on agricultural extension service.

\subsection{Objective}

Specifically, the objective of these researches is to determine the general information of farmers and their perception on the effectiveness of extension services render by the extension personnel.

\subsection{Justification}

Information of farmers and their perception on extension services provides and promotes participatory approach. Thus, improving demand-driven extension services, which facilitate ways for assisting farmers through increasing food production, poverty reduction and uplifting farmer's standard of living.

\subsection{Methodology}

This research was conducted in Kano State of Nigeria in which multistage sampling technique was used. Danbatta, Gaya and Madobi local governments were purposively selected out of the 44 local governments in the state. At second stage, three ward one each from one of the selected local governments were randomly selected (i.e. Ajumawa, Wudilawa and Madobi ward). Similarly, one village from each ward was randomly selected. Thereafter, 40 households were randomly selected from each village. The total number of sample respondents was 120, i.e. 40 households from each village. The data collected was analyzed with the help of SPSS using descriptive statistics, Likert scale and standard deviation [10].

\section{Result and Discussions}

\subsection{Age}

The result in Table 1, shows that 61 out of the 120 respondent's age are 45 years and below and 35 are between 46 - 55 years old. Implying, that majority of the farmers are physically active in agricultural production, as well as adoption of improved agricultural technologies.

\subsection{Education}

It was found that 105 of the respondent are literate while 15 are illiterate. Thus, 57\% of the respondents have attended senior secondary school and $7 \%$ had post-secondary education. Similarly, $19 \%$ attended primary education while $17 \%$ attended junior secondary education. These indicate that the level of education of the farmers will facilitate effective communication and farmers need to be literate to responds rationally to new technologies.

\subsection{Farming Experience}

The result indicates that, $63 \%$ of the farmers have more than decade of farming experience as shown in Table 2.

Table 1. Age-wise distribution of respondents.

\begin{tabular}{|c|c|c|c|c|c|c|c|c|c|c|}
\hline \multirow[t]{2}{*}{ Location } & \multicolumn{2}{|c|}{ Illiterate } & \multicolumn{2}{|c|}{ Literate } & \multirow[t]{2}{*}{ Total } & \multicolumn{4}{|c|}{ Level of Education } & \multirow[t]{2}{*}{ Total } \\
\hline & No & $\%$ & No & $\%$ & & Primary & Junoir & Senoir & Post-sec & \\
\hline Ajumawa & 3 & 8 & 37 & 93 & 40 & $6(16)$ & $2(5)$ & $26(70)$ & $3(8)$ & 37 \\
\hline Wudilawa & 2 & 5 & 38 & 95 & 40 & $7(18)$ & $7(18)$ & 21(55) & $3(8)$ & 38 \\
\hline Madobi & 10 & 25 & 30 & 75 & 40 & $7(23)$ & $9(30)$ & 13(43) & 1(3) & 30 \\
\hline Total & 15 & 13 & 105 & 88 & 120 & 20(19) & 18(17) & $60(57)$ & $7(7)$ & 105 \\
\hline
\end{tabular}

Source: Field survey. 
Thus, indicating that agriculture is an important source for their livelihood. Hence, committed to it.

\subsection{Extension Service}

Ineffective or inappropriate extension service contributes to decline in agricultural production. Thus, extension is a link between farmers, researchers and extension institution or organization. Table 3 shows that, $68 \%$ of the farmers had contact with extension service while 32\% had not. However, 31 farmers out of 40 farmers interviewed in Madobi had no contact with extension. But 38 and 35 respondents in Wudilawa and Ajumawa had contact with extension service.

\subsection{Ranking of Extension Methods Used by Extension Personnel}

The ranks assigned to each methods used by extension service in innovation dissemination among farmers was determined using a 5 point Likert scale [2]. Table 4 and Table 5 show that, the farmers assigned a rate of v.poor, poor, average, good, and v.good to rate each method. Accordingly, 1, 2, 3, 4 and 5 scores were also assigned to each. The weighted scores of each method determine its rank as obtained by multiplying the frequency of responses from each column. The result indicates that radio was ranked 1 with mean $(\mathrm{m}=23.80)$ and standard deviation $(S D=27.25)$, farm and home visit ranked 2 with $m=18.40$ and $S D=18.24$, print materials ranked 3 with $\mathrm{m}=19.40$ and $\mathrm{SD}=15.14$. However, office calls ranked 8 with $\mathrm{m}=12.80$ and $\mathrm{SD}=12.64$.

Table 2. Distribution of respondents according to farming experience.

\begin{tabular}{|c|c|c|c|c|c|c|c|c|c|}
\hline \multirow[t]{3}{*}{ Location } & \multicolumn{8}{|c|}{ Farming Experience (years) } & \multirow[t]{3}{*}{ Total } \\
\hline & \multicolumn{2}{|c|}{$5-10$} & \multicolumn{3}{|c|}{$11-15$} & \multicolumn{3}{|c|}{16 and above } & \\
\hline & No. & $\%$ & \multicolumn{2}{|c|}{ No. } & $\%$ & \multicolumn{2}{|c|}{ No. } & $\%$ & \\
\hline Ajumawa & 17 & 43 & \multicolumn{2}{|c|}{12} & 30 & \multicolumn{2}{|c|}{11} & 28 & 40 \\
\hline Wudilawa & 11 & 28 & \multicolumn{2}{|c|}{15} & 38 & \multicolumn{2}{|c|}{14} & 35 & 40 \\
\hline Madobi & 10 & 25 & \multicolumn{2}{|c|}{11} & 28 & \multicolumn{2}{|c|}{19} & 48 & 40 \\
\hline Total & 38 & 32 & \multicolumn{2}{|c|}{38} & 32 & \multicolumn{2}{|c|}{44} & 37 & 120 \\
\hline \multicolumn{10}{|c|}{ Respondents Age (in years) } \\
\hline \multirow[t]{2}{*}{ Table Location } & \multicolumn{2}{|c|}{ Up to 35} & \multicolumn{2}{|c|}{$36-45$} & \multicolumn{2}{|c|}{$46-55$} & \multicolumn{2}{|c|}{56 and above } & Total \\
\hline & No. & $\%$ & No. & $\%$ & No. & $\%$ & No. & $\%$ & \\
\hline Ajumawa & 15 & 38 & 9 & 23 & 11 & 28 & 5 & 13 & 40 \\
\hline Wudilawa & 8 & 20 & 7 & 18 & 15 & 38 & 10 & 25 & 40 \\
\hline Madobi & 13 & 33 & 10 & 25 & 9 & 23 & 8 & 20 & 40 \\
\hline Total & 36 & 90 & 26 & 65 & 35 & 88 & 23 & 58 & 120 \\
\hline
\end{tabular}

Source: Field survey.

Table 3. Respondents contact with extension personnel.

\begin{tabular}{|c|c|c|c|c|c|}
\hline \multirow[t]{3}{*}{ Location } & \multicolumn{4}{|c|}{ Contact with Extension Personnel } & \multirow[t]{3}{*}{ Tota } \\
\hline & \multicolumn{2}{|c|}{ Yes } & \multicolumn{2}{|c|}{ No } & \\
\hline & No. & $\%$ & No. & $\%$ & \\
\hline Ajumawa & 35 & 88 & 5 & 13 & 40 \\
\hline Wudilawa & 38 & 95 & 2 & 5 & 40 \\
\hline Madobi & 9 & 23 & 31 & 78 & 40 \\
\hline Total & 82 & 68 & 38 & 32 & 120 \\
\hline
\end{tabular}

Source: Field survey. 
Table 4. Perceived effectiveness of methods used by extension personnel.

\begin{tabular}{|c|c|c|c|c|c|c|c|c|}
\hline \multirow[t]{2}{*}{ Location } & \multirow[t]{2}{*}{ Activities } & \multicolumn{6}{|c|}{ Perceived Effectiveness of Extension Methods } & \multirow[b]{2}{*}{ Total } \\
\hline & & No Activity & V.Poor(1) & Poor(2) & Average(3) & Good(4) & V.Good(5) & \\
\hline Aajumawa & & 12(30) & $1(2.5)$ & 2(5) & $14(35)$ & $8(20)$ & $3(7.5)$ & 40 \\
\hline Wudilawa & Farm/Home Visit & $4(10)$ & $0(0)$ & $0(0)$ & $15(37.5)$ & $17(42.5)$ & $4(10)$ & 40 \\
\hline Madobi & & 12(30) & $2(5)$ & $1(2.5)$ & $12(30)$ & $10(25)$ & $3(7.5)$ & 40 \\
\hline Ajumawa & & $14(35)$ & $4(10)$ & $5(12.5)$ & 13(32.5) & $4(10)$ & $0(0)$ & 40 \\
\hline Wudilawa & Office Calls & $9(22.5)$ & $0(0)$ & $1(2.5)$ & $18(45)$ & $12(30)$ & $0(0)$ & 40 \\
\hline Madobi & & $33(82.5)$ & $3(7.5)$ & 2(5) & $2(5)$ & $0(0)$ & $0(0)$ & 40 \\
\hline Ajumawa & & $10(25)$ & $1(2.5)$ & $6(15)$ & $13(32.5)$ & $8(20)$ & 2(5) & 40 \\
\hline Wudilawa & Demonstration Plots & $3(7.5)$ & $0(0)$ & $1(2.5)$ & $15(37.5)$ & $18(45)$ & $3(7.5)$ & 40 \\
\hline Madobi & & $22(55)$ & $3(7.5)$ & $10(25)$ & 2(5) & $3(7.5)$ & $0(0)$ & 40 \\
\hline Ajumawa & & $4(10)$ & $3(7.5)$ & $8(20)$ & $14(35)$ & $7(17.5)$ & $4(10)$ & 40 \\
\hline Wudilawa & Farmer Training & $9(22.5)$ & $0(0)$ & $1(2.5)$ & $13(32.5)$ & $16(40)$ & $1(2.5)$ & 40 \\
\hline Madobi & & $7(17.5)$ & $9(22.5)$ & $8(20)$ & $14(35)$ & 2(5) & $0(0)$ & 40 \\
\hline Ajumawa & & $2(5)$ & $4(10)$ & $5(12.5)$ & $23(57.5)$ & $5(12.5)$ & $1(2.5)$ & 40 \\
\hline Wudilawa & Local Fair & $13(32.5)$ & $0(0)$ & $0(0)$ & $16(40)$ & $11(27.5)$ & $0(0)$ & 40 \\
\hline Madobi & & $13(32.5)$ & $3(7.5)$ & $8(20)$ & $14(35)$ & $1(2.5)$ & $1(2.5)$ & 40 \\
\hline Ajumawa & & $8(20)$ & $3(7.5)$ & $8(20)$ & $11(27.5)$ & $7(17.5)$ & $3(7.5)$ & 40 \\
\hline Wudilawa & Workshop & $4(10)$ & $0(0)$ & $0(0)$ & $21(52.5)$ & $15(37.5)$ & $0(0)$ & 40 \\
\hline Madobi & & $18(45)$ & $3(7.5)$ & $9(22.5)$ & $2(5)$ & $8(20)$ & $0(0)$ & 40 \\
\hline Ajumawa & & $0(0)$ & $0(0)$ & $1(2.5)$ & $10(25)$ & $23(57.5)$ & $6(15)$ & 40 \\
\hline Wudilawa & Radio & $1(2.5)$ & $0(0)$ & $0(0)$ & $4(10)$ & $18(45)$ & $17(42.5)$ & 40 \\
\hline Madobi & & $0(0)$ & $1(2.5)$ & $0(0)$ & $3(7.5)$ & 25(62.5) & $11(27.5)$ & 40 \\
\hline Ajumawa & & $4(10)$ & $3(7.5)$ & $3(7.5)$ & 15(37.5) & $12(30)$ & $3(7.5)$ & 40 \\
\hline Wudilawa & Print Materials & $11(27.5)$ & $0(0)$ & $0(0)$ & $11(27.5)$ & $16(40)$ & $2(5)$ & 40 \\
\hline Madobi & & $8(20)$ & $4(10)$ & $12(30)$ & $14(35)$ & $2(5)$ & $0(0)$ & 40 \\
\hline
\end{tabular}

Note: Figures in parenthesis show percentages.

Table 5. Ranking of extension methods used by extension personnel.

\begin{tabular}{|c|c|c|c|c|}
\hline Extension Methods & Weighted Score & Rank Order & Mean & Standard Deviation \\
\hline Farm/Home Visit & 322 & 2 & 18.40 & 18.24 \\
\hline Office Calls & 186 & 8 & 12.80 & 12.64 \\
\hline Demonstration Plots & 269 & 7 & 17.00 & 12.51 \\
\hline Farmer Training & 294 & 4 & 20.00 & 13.82 \\
\hline Local Fair & 270 & 6 & 18.40 & 20.17 \\
\hline Workshop & 277 & 5 & 18.00 & 13.87 \\
\hline Radio & 488 & 1 & 23.80 & 27.25 \\
\hline Print Materials & 302 & 3 & 19.40 & 15.14 \\
\hline
\end{tabular}

Source: Calculation by author.

\section{Conclusion}

Agricultural extension service requires regular supervision to ensure that effective and appropriate information 
is disseminated at the right time and placed to the right people. This will assist farmers achieved high income and improve living standard through agricultural production, particularly, Madobi area, where the majority of farmers (77\%) have no contact with the extension service. Thus, extension should work according to farmers need and resources.

\section{References}

[1] Federal Government of Nigeria (2008) National Food Security Program. Federal Ministry of Water Resources, Abuja.

[2] Mohammad, A.L. andAtte, O.A. (2006) An Analysis of Agricultural Production in Nigeria. African Journal of General Agriculture, 2, 1-4.

[3] Nigeria National Planning Commission (2004) Meeting Everyone’s Need. National Economic Empowerment and Development Strategy.

www.researchgate.net/publication/44834588_meeting_everyones’_NEEDS_national_economic_empowerment_andde velopment_strategy

[4] Federal Government of Nigeria (2009) The Vision and Development Priorities: Vision 20: 2020. National Planning Commission, Abuja.

[5] Bardsley, J. (1982) Farmer's Assessment of Information and its Source. School of Agriculture and Forestry, Melbourne, $11-12$.

[6] Ifenkwe, G. (2012) Agent-Related Factors Affecting the Performance of Agricultural Extension Staff in Abia State, Nigeria. Journal of Agricultural Science, 3, 45-48.

[7] Arokoyo, T. (1998) Agricultural Technology Development and Dissemination: A Case of Ghana and Nigeria Experiences. Technical Center for Agriculture and Rural Cooperation, Wageningen.

[8] Akinagbe, A.O. (2010) Challenges of Farmer-Led Extension Approach in Nigeria. World Journal of Agricultural Sciences, 3, 353-359.

[9] Madukwe, M. (2010) Nigeria’s Extension Service: Practice without Policy. University of Nigeria, Nsukka. www.unn.edu.ng/files/inaugural\%20lecture\%20Documents/Agric\%science/30th\%lecture

[10] Ayesha, K. and Mohammad, A. (2012) Farmer’s Perception of Extension Methods Used by Extensi Personnel for Dissemination of New Agricultural Technologies in Kyber Pekhtunkhwa, Pakistan. Sarhad Journal of Agriculture, 28, 511-520.

[11] Anandajayasekeram, P., Ranjitha, P., Sindu, W. and Dirk, H. (2008) Concept and Practice of Extension in Developing Countries. International Livestock Resources Institute, Addisababa, 51-76. 